DOI 10.4467/2543733XSSB.21.009.13802

\title{
POLSKO-NIEMIECKIE STOSUNKI W SEJMOWEJ I SENACKIEJ DEBACIE W LATACH 1989-1991
}

\author{
German-Polish Relations in the Sejm and Senate Debate \\ in 1989-1991
}

\begin{abstract}
Summary
The paper concerns the position of Polish MPs and senators on shaping the principles of German-Polish cooperation in a situation in which Poland regains full sovereignty in foreign policy. The position of Polish deputies was analysed on the basis of stenographic reports from plenary sessions of the Sejm and Senate concerning the preparation and ratification of treaties with Germany on confirming the border and on good neighbourhood. In particular, it was a question of examining whether MPs and senators supported the concept of a German-Polish community of interest, which was defined and presented in the Sejm by Foreign Minister Krzysztof Skubiszewski. During the ratification debate, supporters of both treaties pointed out that they enabled Poland to leave the Eastern Bloc, making Poland independent of the support of the USSR for the western border. They also provided an opportunity for German support on Poland's way to the European Communities. MPs and senators understood that it was possible to build a German-Polish community of interest on the basis of supporting and expanding the integration process and thus completely change Poland's geopolitical situation. This did not mean that the solutions adopted in the treaty on good neighbourhood, especially with regard to compensation, the status of Poles in Germany and the German minority in Poland, were fully accepted.
\end{abstract}

Key words: Sejm, Senate, Polish-German German-Polish Border Treaty, Polish-German treaty on good neighborliness, Polish-German mutual interests.

Slowa kluczowe: Sejm, Senat, polsko-niemiecki traktat o potwierdzeniu granicy, polsko-niemiecki traktat o dobrym sąsiedztwie, wspólnota polsko-niemieckich interesów. 


\section{Wprowadzenie}

Parlament (Sejm i Senat) wybrany 4 czerwca 1989 r. po raz pierwszy od czasu zakończenia drugiej wojny światowej mógł w swobodny sposób wypowiadać się w kwestii polityki zagranicznej, a rząd Polski odzyskał możliwość jej niezależnego prowadzenia. Polska mogła więc samodzielnie określić swoje stanowisko wobec zjednoczenia Niemiec, kwestii polsko-niemieckiej granicy i kształtu wzajemnych stosunków. Minister spraw zagranicznych Krzysztof Skubiszewski poparł proces jednoczenia Niemiec, doprowadził do traktatowego potwierdzenia istniejącej granicy na Odrze i Nysie Łużyckiej oraz sformułował zakres polsko-niemieckiej wspólnoty interesów, która miała stać się podstawą przyszłych relacji.

Jak dalece Sejm i Senat akceptowały tę politykę, zwłaszcza zaś koncepcję wspólnoty interesów, stanowi zasadnicze pytanie. W poszukiwaniu odpowiedzi, analizie została poddana dyskusja w Sejmie i w Senacie dotycząca negocjacji z Niemcami i ratyfikacji podpisanych traktatów: Traktatu między Rzeczapospolita Polskq a Republika Federalnq Niemiec o dobrym sqsiedztwie i przyjaznej wspótpracy, podpisanego w Bonn dnia 17 czerwca $1991 \mathrm{r}$. oraz Traktatu między Rzeczapospolita Polska a Republikq Federalna Niemiec o potwierdzeniu istniejacej między nimi granicy, podpisanego w Warszawie dnia 14 listopada $1990 \mathrm{r}$.

Podstawą źródłową stały się zatem w pierwszej kolejności sprawozdania stenograficzne obu izb. Natomiast dokumenty związane z wynegocjowaniem i ratyfikacją obu traktatów, opracowane przez Jana Barcza i Mieczysława Tomalę w zbiorze Polska-Niemcy. Dobre sqsiedztwo i przyjazna wspótpraca, pełniły rolę pomocnicza, podobnie jak dokumenty dyplomatyczne wydane przez Włodzimierza Borodzieja, Polska wobec zjednoczenia Niemiec 1989-1991 oraz opracowania Mieczysława Tomali, Władysława Czaplińskiego, Witolda M. Góralskiego, Jana Barcza, Anny Wolf-Pawęskiej, Jerzego Sułka i wielu innych.

\section{Założenia polityki rządu Tadeusza Mazowieckiego wobec państw niemieckich}

Tadeusz Mazowiecki powierzył kierowanie Ministerstwem Spraw Zagranicznych Krzysztofowi Skubiszewskiemu 13 września 1989 r. Nowy minister wyznaczył początkowo odrębne cele w stosunku do Niemieckiej Republiki Demokratycznej (NRD) i do Republiki Federalnej Niemiec (RFN). Zapowiedział odideologizowanie relacji z NRD, a następnie przywrócenie ruchu osobowego zawieszonego od 1981 r., zmniejszenie opłat pobieranych za tranzyt do Berlina Zachodniego i podniesienie sprawy roszczeń z czasów drugiej wojny światowej ${ }^{1}$.

W odniesieniu do RFN Skubiszewski dostrzegał konieczność ożywienia stosunków, będących w zupełnym zastoju od 1981 r. Wprawdzie na początku 1988 r. rozpoczęły się, z pominięciem Ministerstwa Spraw Zagranicznych (MSZ), rozmowy pełnomocników premiera Mieczysława Rakowskiego (Ernesta Kuczy) i kanclerza Helmuta Kohla (Horsta

\footnotetext{
${ }^{1}$ Obroty handlowe z NRD K. Skubiszewski oceniał w 1989 r. na 2,5 mld rubli; liczbę pracujących w NRD Polaków na 30 tys., a liczbę osób wyjeżdżających rocznie do NRD w ramach wymiany na 300 tys., Sprawozdanie stenograficzne z posiedzenia Komisji Spraw Zagranicznych Sejmu i Senatu w dniu 17 X 1989 r. (dalej Posiedzenie KSZ Sejmu i Senatu), s. 3, 26-27.
} 
Teltschika), ale strona niemiecka przeciągała je, czekając na rozwój sytuacji w Polsce. Premier Tadeusz Mazowiecki podtrzymał tę formułę rozmów (ku niezadowoleniu Skubiszewskiego), ale wyznaczył nowego pełnomocnika, Mieczysława Pszona. Teltschik i Pszon przygotowali dziewięć umów - w tym dotyczące nazewnictwa geograficznego, wznowienia współpracy prawnej, wymiany młodzieży, ochrony środowiska, współpracy naukowo-technicznej, ochrony zdrowia, otwarcia w obu krajach instytutów naukowych, otwarcia konsulatów generalnych w Krakowie i Hamburgu oraz atachatów wojskowych przy ambasadach obu państw, oraz deklarację, którą mieli podpisać szefowie obu rząów podczas zaplanowanej na listopad 1989 r. wizyty Helmuta Kohla w Polsce. Jednocześnie Polska uzyskała częściowe umorzenie kredytu ,jumbo” (1 mld marek) zaciągniętego w 1975 r. oraz przewalutowanie pozostałej części na złote. RFN postanowiła otworzyć w Polsce gwarancję Hermesa, co oznaczało, że da zabezpieczenie kredytów swoim inwestorom w Polsce ${ }^{2}$.

Stosunki z RFN Skubiszewski uważał za bardziej skomplikowane niż z NRD. Podkreślał, że RFN była najważniejszym partnerem Polski we wszystkich dziedzinach, chętnie przyznawała wizy Polakom, a po wprowadzeniu w Polsce stanu wojennego z jej terytorium wysłano do Polski $30 \mathrm{mln}$ paczek z pomocą dla polskich obywateli ${ }^{3}$, dostrzegał również zbieżność poglądów obu państw na kwestie porządku europejskiego. Nie zamierzał jednak ignorować faktu, że niemieckie sądy orzekały, stojąc na stanowisku granic z 1937 r., a niemieccy politycy wypowiadali niepokojące opinie na temat zachodniej granicy Polski w przypadku zjednoczenia Niemiec ${ }^{4}$. Nie uspokajało go oświadczenie ministra spraw zagranicznych RFN Hansa Dietricha Genschera z września 1989 r., że granica na Odrze i Nysie Łużyckiej istnieje i będzie istniała w przyszłości ${ }^{5}$.

Skubiszewski uważał, że w świetle prawa międzynarodowego postanowienia układu z 1970 r. oznaczały zgodę RFN na przebieg granicy na linii Odry-Nysy Łużyckiej. Dostrzegał jednak, że chociaż w RFN takiej interpretacji nie odrzucano, to unikano używania słowa „uznanie” (Anerkennung), co skłaniało go do stwierdzenia, że polska granica za-

${ }^{2}$ Posiedzenie KSZ Sejmu i Senatu 17 X 1989 r., s. 23-24; Polska wobec zjednoczenia Niemiec 1989-1991, pod red. W. Borodzieja, Warszawa 2006. Według W. Borodzieja RFN była głównym polskim wierzycielem: w 1987 r. polski dług wynosił niemal 8 mld dolarów, a nieobsłużone zaległości 1 mld marek niemieckich, zob. W. Borodziej, Wstęp, [w:] Polska wobec zjednoczenia Niemiec..., s. 15, s. 17-18.

${ }^{3}$ Według W. Borodzieja w 1981 r. z RFN do Polski przybyło 2 mln przesyłek, ale akcja wysyłania paczek rozwijała się, a łączną pomoc indywidualną i społeczną W. Borodziej szacuje na setki milionów marek, zob. W. Borodziej, Wstęp..., s. 14.

${ }^{4}$ Chodziło o wypowiedzi ministra finansów Theo Weigla i minister do spraw wewnątrzniemieckich Dorothee Wilms, utrzymujących, że problem Niemiec nadal jest otwarty, łącznie ze sprawą terenów za Odrą i Nysą, W. Borodziej, Wstep ...s. 23. Wypowiedzi te wynikały z orzecznictwa Federalnego Trybunału Konstytucyjnego RFN. Zgodnie z nim Rzesza nadal istniała jako bierny podmiot prawa międzynarodowego w granicach z 31 XII 1937 r. RFN była częściowo identyczna z Rzeszą, ponieważ trwała na części jej terytorium. Wszelkie zobowiązania podejmowane przez RFN i NRD obowiązywały tylko te państwa i nie angażowały Rzeszy. Jakiekolwiek decyzje dotyczące cesji niemieckiego terytorium były możliwe dopiero po zjednoczeniu i odbudowaniu jedności terytorialnej. Układ podpisany przez NRD w 1950 i układ z 1970 r. podpisany przez RFN nie stanowiły podstawy cesji terytorialnej i wiązały oba państwa niemieckie tylko do momentu ich zjednoczenia, szerzej o tym: W. Czapliński, Polskie pozycje prawne wobec Niemiec popoczdamskich $w$ świetle prawa międzynarodowego. Agresja-terytorium-obywatelstwo, [w:] Polska - Niemcy 1945-2007. Od konfrontacji do wspótpracy i partnerstwa w Europie. Studia i dokumenty, pod red. Witolda M. Góralskiego, Warszawa 2007, s. 51.

${ }^{5}$ Posiedzenie KSZ Sejmu i Senatu 17 X 1989 r., s. 3-6. 
chodnia „Nie jest w RFN atakowana wprost, ale drogą okrężną". Jednak mimo kontrowersji dotyczących granicy nie zamierzał w żaden sposób utrudniać zjednoczenia Niemiec, choć uważał, że powinno się dokonać zgodnie z zasadami ogólnoeuropejskiego bezpieczeństwa $^{7}$. Nie dostrzegał żadnego militarnego zagrożenia ze strony RFN, dopóki była członkiem NATO, i nie obawiał się żadnych negatywnych konsekwencji zagwarantowania przez Polskę praw niemieckiej mniejszości w Polsce. Był świadom rozbieżności między stanowiskiem polskim a niemieckim w kwestii odpowiedzialności RFN za krzywdy wyrządzone Polakom w czasie wojny i popierał utworzenie stowarzyszenia, które miało się zająć tym problemem. Uważał, że obok normalizacji stosunków między Polską i RFN, najważniejsze było pojednanie obu narodów na płaszczyźnie państwowej i społecznej oraz realizowanie wspólnych przedsięwzięć ${ }^{8}$.

\section{Posiedzenie Komisji Spraw Zagranicznych Sejmu i Senatu 17 października 1989 r.}

Wspólne posiedzenie obu Komisji było poświęcone zbliżającej się wizycie Helmuta Kohla w Polsce. Początkowo dyskusja koncentrowała się wokół obaw o wpływ zjednoczenia Niemiec na proces jednoczenia Europy i sytuację Polski. Wyrażali je przede wszystkim posłowie Polskiej Zjednoczonej Partii Robotniczej (Krzysztof Komornicki, Włodzimierz Cimoszewicz, Józef Oleksy) oraz Jan Czaja ze Zjednoczonego Stronnictwa Ludowego. Obawy przed wykupywaniem przez Niemców nieruchomości na „Ziemiach Odzyskanych” i negatywnymi skutkami zagwarantowania praw niemieckiej mniejszości w Polsce żywił Stefan Myszkiewicz-Niesiołowski z Obywatelskiego Klubu Parlamentarnego (OKP). Wielu posłów niepokoiło niejednoznaczne stanowisko Helmuta Kohla w kwestii polskiej granicy zachodniej ${ }^{9}$.

Nową jakość do tej dyskusji wniósł Bronisław Geremek (OKP), przewodniczący Komisji Spraw Zagranicznych Sejmu. Stwierdził, że PZPR podtrzymywała pogląd o stałym niemieckim zagrożeniu jako element legitymizujący jej władzę w Polsce. Umacniała przekonanie, że była jedyną siłą polityczną zdolną zagwarantować dobre stosunki z ZSRR i ostateczny charakter polskiej granicy zachodniej. Geremek zapowiedział pozbawienie jej tej legitymizacji. Jego zdaniem interesom Polski najbardziej zagrażało traktowanie zjednoczenia Niemiec jako zagrożenia polskiej racji stanu. Tymczasem był to element demokratycznych przemian w Europie, które Polska popierała. Wezwał, by w dyskusji o polskiej polityce zagranicznej nie stroić się w pióra obrońcy polskich granic. Nadszedł bowiem czas, by znaleźć sposób na nowoczesne kształtowanie stosunków z sąsiadami Polski, w tym z państwami niemieckimi ${ }^{10}$.

W ślad za Geremkiem posłowie OKP wzywali do odejścia od utrwalonych przez komunistyczną propagandę stereotypów związanych z niemieckim zagrożeniem. Należało

\footnotetext{
${ }^{6}$ Posiedzenie KSZ Sejmu, 8 IX 1989 r., s. 6.

${ }^{7}$ Posiedzenie KSZ Sejmu, 8 IX 1989 r., s. 4-5, 6-7.

${ }^{8}$ Posiedzenie KSZ Sejmu i Senatu 17 X 1989 r., s. 18, 20-22. Polska z niezrozumiałych powodów zrzekła się odszkodowań w stosunku do NRD, a nie reparacji, jak to zrobił ZSRR, W. Borodziej, Wstęp...s. 15.

${ }^{9}$ Posiedzenie KSZ Sejmu i Senatu 17 X 1989 r., s. 7-10, 12-13.

${ }^{10}$ Posiedzenie KSZ Sejmu i Senatu 17 X 1989 r., s. 11.
} 
raczej skoncentrować się na realizacji takiego pojednania z RFN, jakie stało się udziałem Francji ${ }^{11}$.

W tym duchu wypowiadali się również zaproszeni eksperci. Mieczysław Tomala (Polski Instytut Spraw Międzynarodowych) postulował zastąpienie teorii dwóch wrogów budową przyjacielskich stosunków z sąsiadami. Artur Hajnicz (Ośrodek Studiów Międzynarodowych Senatu) przekonywał, że chociaż Polska i RFN znalazły się w pułapce granicy z 1937 r. i w pewnym sensie były w stanie wojny prawnej, jednak nie istniało niebezpieczeństwo niemieckiego rewizjonizmu ${ }^{12}$.

Janusz Onyszkiewicz (OKP) przyznawał, że w stosunkach z Niemcami należało się skoncentrować na bezpieczeństwie granic. Wykluczał jednak prowadzenie polityki w duchu, jaki prezentował prezydent Wojciech Jaruzelski, przekonując, że Władysław Gomułka wziął udział w inwazji na Czechosłowację w 1968 r. w obawie przed niemieckim zagrożeniem. Zdaniem Onyszkiewicza nadszedł czas, by odrzucić tezę, jakoby zjednoczenie Niemiec wiązało się z podważeniem zachodniej granicy Polski ${ }^{13}$.

\section{Ochłodzenie w stosunkach Polski i RFN po wizycie Helmuta Kohla}

Wizyta kanclerza RFN w Polsce (9-14 listopada 1989 r.), przerwana ze względu na zburzenie muru berlińskiego, zakończyła się ostatecznie podpisaniem 14 listopada $1989 \mathrm{r}$. wspólnego polsko-niemieckiego oświadczenia przewidującego ożywienie dwustronnych stosunków i rozwój szeroko pojętej współpracy obu państw ${ }^{14}$.

Jednak już 29 listopada 1989 r. polski ambasador w Bonn Ryszard Kulski zwrócił uwagę, że Helmut Kohl w planie zjednoczenia Niemiec - upublicznionym dzień wcześniej, zupełnie nie odnosił się do sprawy granic, w tym do newralgicznej granicy na Odrze i Nysie Łużyckiej. W swym szyfrogramie sugerował m.in. ,zintensyfikowanie działań dla uzgodnienia poglądów w tych sprawach z najbardziej zainteresowanymi na Wschodzie i Zachodzie"15.

W tej sytuacji Krzysztof Skubiszewski podjął zabiegi o włączenie sprawy granicy na Odrze i Nysie Łużyckiej do negocjacji czterech państw okupacyjnych i dwóch państw niemieckich w sprawie zjednoczenia (konferencje $2+4$ ). Sformułował również postulat, by oba państwa niemieckie jeszcze przed zjednoczeniem parafowały traktat w sprawie granicy, który podpisałyby i ratyfikowały zjednoczone Niemcy. Jednocześnie zademonstrował zbliżenie z NRD, czego wyrazem była wizyta wschodnioniemieckiej delegacji na czele z premierem Hansem Modrowem w Warszawie 16 lutego $1990 \mathrm{r}$.

Hans Modrow, występując na wspólnym posiedzeniu Komisji Spraw Zagranicznych Sejmu i Senatu, zapewnił, że demokratyczne przemiany po obu stronach Odry i Nysy

\footnotetext{
${ }^{11}$ Posiedzenie KSZ Sejmu i Senatu 17 X 1989 r. s. 6-10, 13-14.

${ }^{12}$ Posiedzenie KSZ Sejmu i Senatu 17 X 1989 r., s. 15, 18.

${ }^{13}$ Posiedzenie KSZ Sejmu i Senatu 17 X 1989 r., s. 16-17.

${ }^{14}$ W. M. Góralski, Polsko-niemiecka wspólnota interesów. Geneza, dokonania, zagrożenia, [w:] Polska Niemcy 1945-2007. Od konfrontacji do wspólpracy i partnerstwa w Europie. Studia i dokumenty, s. 313; pełny tekst deklaracji w: Polska wobec zjednoczenia Niemiec..., s. 174-182.

${ }^{15}$ Szyfrogram ambasady w Kolonii nt. 10-punktowego planu kanclerza federalnego z 29 XI 1989 r., [w:] Polska wobec zjednoczenia Niemiec...., s. 189.
} 
umożliwiły budowanie zaufania i współpracy nie tylko rządów, ale i narodów, i w konsekwencji zakończyło się myślenie w kategoriach bloków. Jednocześnie zapowiedział włączenie procesu jednoczenia Niemiec w ogólnoeuropejski proces integracji. Uznając za nadal wiążący pod względem międzynarodowym układ zgorzelecki z 6 lipca 1950 r., przyznał, że Polska ma prawo zabezpieczyć swe interesy w trakcie rozmów o granicach i problemach bezpieczeństwa ${ }^{16}$.

Przewodniczący Komisji Spraw Zagranicznych Senatu Janusz Ziółkowski poświadczył o poparciu dla zjednoczenia Niemiec w imię prawa narodów do samostanowienia i jednoczenia Europy. Wyraził jednak nadzieję, że zjednoczone Niemcy zagwarantują granice na Odrze i Nysie Łużyckiej. Wezwał, by pamiętając o przeszłości, zwrócić się ku przyszłości, uwolnić od stereotypów, szowinizmu i uprzedzeń: „Nie ma bowiem jakiegokolwiek fatalizmu między narodami. Od nas zależy, jaka będzie przyszłość. Niechaj każdy naród będzie wolny i żyje w wolnej, zjednoczonej Europie"li.

\section{Sformułowanie koncepcji polsko-niemieckiej wspólnoty interesów}

Kontrowersje wokół uznania granicy na Odrze i Nysie Łużyckiej nie stanowiły dla Skubiszewskiego przeszkody w rozwijaniu koncepcji współpracy z Niemcami, niezbędnej, jeśli Polska chciała realizować politykę zbliżenia z Zachodem. 22 lutego 1990 r. w trakcie VI Forum Niemiecko-Polskiego w Poznaniu określił polsko-niemieckie pojednanie jako fakt dokonany, a „takie lub inne tarcia” uznał za nieuniknione i możliwe do usunięcia. Podkreślał jednak, że Niemcy musiały zrozumieć zarówno znaczenie swego zjednoczenia dla ich sąsiadów, jak również uznać konieczność istnienia silnej Polski między Niemcami a ZSRR. Z tego powodu Polska w pierwszej kolejności dążyła do wypracowania traktatu o granicy, mającego status regulacji traktatu pokojowego. Natomiast celem na przyszłość było zbudowanie polsko-niemieckiej wspólnoty interesów jako ważnego składnika międzynarodowego porządku w jednoczącej się Europie ${ }^{18}$.

O budowaniu wspólnoty interesów mówiła również instrukcja Ministerstwa Spraw Zagranicznych dla marszałka Senatu Andrzeja Stelmachowskiego z 27 kwietnia 1990 r., sporządzona przed wizytą prezydenta RFN Richarda von Weizsäckera w Warszawie (2-5 maja 1990 r.). Obok spraw związanych z ostatecznym potwierdzeniem granicy na Odrze i Nysie Łużyckiej, wypłaceniem odszkodowań osobom pokrzywdzonym przez Trzecią Rzeszę i wzajemną ochroną praw mniejszości narodowych, Stelmachowski miał poruszyć kwestię budowania w przyszłości wspólnoty polsko-niemieckich interesów w jednoczącej się Europie. Przez wspólnotę interesów rozumiano skierowanie wzajemnych relacji ku przyszłości, usunięcie z niej punktów spornych i rozszerzenie płaszczyzny współpracy. Stosunki z Niemcami miały mieć dla Polski strategiczne znaczenie na równi ze stosunkami z ZSRR. Dlatego Polska oczekiwała, że stanie się dla Niemiec ważnym part-

${ }^{16}$ Posiedzenie KSZ Sejmu i Senatu, 16 II 1990 r., s. 292-293.

${ }^{17}$ Posiedzenie KSZ Sejmu i Senatu, 16 II 1990 r., s. 292.

${ }^{18}$ W. M. Góralski, Polsko-niemiecka wspólnota interesów..., s. 314; Przemówienie ministra spraw zagranicznych RP Krzysztofa Skubiszewskiego wygłoszone 22 lutego 1990 r. podczas VI Forum Niemiecko-Polskiego w Poznaniu, [w:] Polska - Niemcy 1945-2007..., s. 361-364. 
nerem, a nie tylko elementem niemiecko-radzieckich stosunków. Stelmachowski miał też uświadomić niemieckim gościom, że Polska pragnie uniknąć sytuacji, w której granica podziału Europy zamiast zniknąć, zostałaby jedynie przesunięta z Łaby na Odrę ${ }^{19}$.

Instrukcja MSZ sugerowała Stelmachowskiemu, by wyraził zrozumienie dla cierpienia Niemców, którzy w wyniku wojny i umowy poczdamskiej zostali wysiedleni ze swych stron ojczystych. Miał też zapewnić, że chociaż skala niesprawiedliwości doznanych przez stronę polską była większa, to jednak Polska w imię porozumienia i pojednania nie zamierzała ciągnąć w nieskończoność rachunku krzywd i wzajemnych rozliczeń. Te bolesne wydarzenia powinny były pozostać przestrogą na przyszłość. Natomiast Niemcy i Polacy, którzy stali się ofiarami wysiedleń, powinni odegrać szczególną rolę w budowaniu porozumienia $^{20}$.

\section{Zamknięcie kwestii granicy na Odrze i Nysie Łużyckiej}

Kwestia granic zjednoczonych Niemiec została rozstrzygnięta na konferencji 2+4 w Paryżu w dniu 17 lipca 1990 r. w obecności Krzysztofa Skubiszewskiego. Komisja Spraw Zagranicznych Sejmu zapoznała się z postanowieniami konferencji paryskiej 25 lipca $1990 \mathrm{r}$.

Posłowie kierowali do Skubiszewskiego szereg pytań, w tym przede wszystkim dotyczące potwierdzenia ostatecznego charakteru polskiej zachodniej granicy w traktacie z Niemcami. Podnoszono także kwestię ponownego rozstrzygnięcia podziału wód Zatoki Pomorskiej i sprawy odszkodowań. Posłów interesowało stanowisko, jakie zajął w Paryżu Związek Radziecki, ponieważ obawiano się najwyraźniej, czy na skutek spotkania Helmuta Kohla z Michaiłem Gorbaczowem w przeddzień konferencji paryskiej, nie osłabło radzieckie poparcie dla polskiego stanowiska ${ }^{21}$.

Skubiszewski poinformował, że w traktacie regulującym kwestię zjednoczenia Niemiec znajdzie się kilka ważnych zapisów: zjednoczone Niemcy obejmą terytoria NRD i RFN w ich dotychczasowych granicach oraz Berlin; zjednoczone Niemcy i Polska potwierdzą istniejącą granicę w formie prawno-międzynarodowego traktatu; zjednoczone Niemcy wyrzekną się roszczeń terytorialnych obecnie i w przyszłości; zjednoczone Niemcy dostosują swoją konstytucję do zasad tej regulacji; mocarstwa zadeklarują że przyjmą w sposób formalny odrębne oświadczenia i zobowiązania obu państw niemieckich i uznają, że oznacza to ostateczne potwierdzenie granic, które nie mogą być zmieniane w przyszłości, ani podważane przez żadne wydarzenia lub okoliczności zewnętrzne. Stwierdzenie to zdaniem Skubiszewskiego uwalniało Polskę od konieczności podpisywania traktatu pokojowego, a jednocześnie nie było gwarancją mocarstw dla granic Niemiec. Rezygnację z podpisania traktatu pokojowego przez RFN Skubiszewski uznał za sukces, ponieważ w interesie Polski leżało nie tyle podpisanie traktatu pokojowego, co sformułowanie, że zapis w kwestii granic odpowiada ,traktatowi pokojowemu” w rozumieniu układu poczdamskiego ${ }^{22}$. Był

\footnotetext{
${ }^{19}$ Archiwum Senatu (dalej AS), Stelmachowski, Zespół 48 teczka Europa, strony niepaginowane.

${ }^{20}$ AS, Stelmachowski, Zespół 48 teczka Europa.

${ }^{21}$ Posiedzenie KSZ Sejmu, 25 VII 1990 r., s. 8-9.

${ }^{22}$ Stanowisko Niemiec wynikało z zapisu układu ogólnego o stosunkach RFN z trzema mocarstwami z 26 V 1952 r., potwierdzonego w 1954 r., który stanowił, że sprawa terytoriów na wschód od Odry-Nysy powinna być zastrzeżona do regulacji pokojowej, a jej celem będzie zapewnienie trwałego pokoju, a nie realizacja
} 
zadowolony z przyjętej formuły, że „Potwierdzenie ostatecznego charakteru granic stanowi istotny element pokojowego porządku w Europie"23.

Tłumaczył posłom, że nie zabiegał o uzyskanie gwarancji granicy na Odrze i Nysie Łużyckiej ze strony mocarstw, ponieważ wyraźnie tego sobie nie życzyły. Poza tym Polska nie była zainteresowana gwarancjami ze strony ZSRR i nie chciała stwarzać wrażenia, że jej granice zależą od gwarancji, które mogą być cofnięte. Podkreślił, że granica zostanie jedynie potwierdzona, bo była już ustalona. Poinformował również, że wbrew pierwotnym zamiarom zostaną podpisane dwa traktaty: o potwierdzeniu granicy, a potem drugi, obejmujący pozostałe sprawy, które wymagały trudnych negocjacji ${ }^{24}$.

Zdaniem Skubiszewskiego Polsce dużo mniej szkodziły rozmowy między Kohlem a Gorbaczowem niż nieprzychylna debata w niemieckiej prasie, dotycząca rzekomych nadmiernych polskich żądań. Poinformował posłów, że ZSRR pomógł Polsce w trakcie przygotowań do konferencji 2+4 w Paryżu i poparł jej stanowisko. W sprawie Zatoki Pomorskiej minister wezwał, by nie kwestionować podpisanej już z NRD umowy (,bo się w tej wodzie utopimy"), nie widząc możliwości wynegocjowania lepszej ${ }^{25}$.

Decyzje podjęte w Paryżu zostały potwierdzone w Traktacie o ostatecznej regulacji w odniesieniu do Niemiec, podpisanym w Moskwie 12 września 1990 r. Następnie 14 listopada 1990 r. został podpisany Traktat między Rzeczapospolita Polska a Republikq Federalnq Niemiec o potwierdzeniu istniejqcej między nimi granicy. Natomiast Traktat między Rzeczapospolita Polskq a Republikq Federalna Niemiec o dobrym sqsiedztwie i przyjaznej współpracy - obejmujący całościowo stosunki polsko-niemieckie, został parafowany 6 czerwca, a podpisany 17 czerwca $1991 \mathrm{r}$.

\section{Debata nad ratyfikacją obu traktatów z Niemcami}

Zadanie uzyskania zgody na ratyfikację traktatu o dobrym sąsiedztwie przez Sejm stanęło przed rządem Jana Krzysztofa Bieleckiego ${ }^{26}$. Jego najbardziej kontrowersyjne zapisy dotyczyły asymetrii w traktowaniu niemieckiej mniejszości w Polsce i Polaków w Niemczech oraz wyłączenia z traktatu kwestii odszkodowań ${ }^{27}$. Protesty mógł również

zasady samostanowienia narodów, S. Parzymies, Stosunki międzynarodowe w Europie 1945-2004, Warszawa 2004, s. 57-59.

${ }^{23}$ Posiedzenie KSZ Sejmu, 25 VII 1990 r., s. 4.

${ }^{24}$ Posiedzenie KSZ Sejmu, 25 VII 1990 r., s. 2-5, 11.

${ }^{25}$ Posiedzenie KSZ Sejmu, 25 VII 1990 r., s. 10-12.

${ }^{26}$ Ratyfikacji przez Sejm podlegał jedynie traktat o dobrym sąsiedztwie, ponieważ nowelizacja konstytucji z 7 IV 1989 r. upoważniała Sejm do udziału w ratyfikacji tylko tych umów, które pociągały za sobą konieczność zmian w ustawodawstwie krajowym lub konsekwencje finansowe. Traktat o potwierdzeniu granicy podlegał ratyfikacji przez prezydenta bez udziału Sejmu. Jednakże ze względu na jego wagę, K. Skubiszewski zwrócił się do Sejmu i Senatu, by przyjęły uchwały wspierające prezydenta w jego ratyfikacji.

${ }^{27} \mathrm{~K}$. Skubiszewski podkreślał, że prawa mniejszości niemieckiej, czyli polskich obywateli identyfikujących się z narodem niemieckim lub niemiecką kulturą i językiem, jak i niemieckich obywateli polskiego pochodzenia oparto na prawie międzynarodowym (art. 20); w traktacie umieszczono klauzulę o ich lojalności wobec państwa zamieszkania (art. 23); Polacy mieszkający w Niemczech, ale nieposiadający niemieckiego obywatelstwa nie byli traktowani jako mniejszość, jednak w drodze wymiany listów między ministrami spraw zagranicznych obu państw zagwarantowano im możliwość korzystania z praw przyznanych mniejszości polskiej; kwestia odszkodowań miała być rozwiązana drogą rządowego porozumienia: RFN miała przekazać sumę ryczałtową powołanej 
budzić zapis o swobodnym obrocie ziemią po wejściu Polski do Wspólnego Rynku i możliwości zakupu nieruchomości przez Niemców w Polsce ${ }^{28}$.

Już 7 czerwca 1991 r. Skubiszewski bezpośrednio po parafowaniu traktatu o dobrym sąsiedztwie przedstawił posłom jego założenia. Podkreślił znaczenie traktatu dla polskiej racji stanu i jej europejskiej opcji, ponieważ stosunki z Niemcami miały determinować polską drogę do Wspólnego Rynku. Niemcy w traktacie zobowiązały się wspierać polskie starania o wejście do Wspólnot (art. 8). Traktat tworzył więc warunki, by Polska i Niemcy budowały wspólnie europejskie bezpieczeństwo i w tym sensie miał również ważne znaczenie dla dobrze pojętego interesu europejskiego ${ }^{29}$.

Podczas pierwszego czytania ustawy o ratyfikacji traktatu o dobrym sąsiedztwie (13 września 1991 r.) Skubiszewski ponownie podkreślał jego znaczenie w budowaniu wspólnoty polskich i niemieckich interesów. Przekonywał, że oba traktaty stanowiły całość: traktat o potwierdzeniu granicy zamykał przeszłość, natomiast traktat o dobrym sąsiedztwie otwierał Polskę i Niemcy ku przyszłości. Przekonywał, że po wydarzeniach drugiej wojny światowej Polacy i Niemcy byli szczególnie zobowiązani do współpracy w imię dobra obu narodów, a wspólnota polskich i niemieckich interesów miała kluczowe znaczenie dla zjednoczonej Europy, której istnienie nie było możliwe bez polsko-niemieckiego porozumienia. W tym sensie traktat miał więc wymiar europejski, a współpraca z Niemcami miała ułatwić Polsce wejście do Wspólnot Europejskich ${ }^{30}$.

Skubiszewski wezwał do zaakceptowania zapisów dotyczących niemieckiej mniejszości w Polsce, ponieważ zostały oparte na dokumentach KBWE, zasadzie lojalności mniejszości w stosunku do państwa zamieszkania i poszanowania nienaruszalności jego granicy ${ }^{31}$. Wskazywał, że Polakom w Niemczech mającym niemieckie obywatelstwo traktat gwarantował prawa, jakie przysługują mniejszościom, a Polakom niemającym obywatelstwa możliwość z ich korzystania. Brak odniesienia w traktacie do sprawy odszkodowań tłumaczył zaniedbaniami rządów Polskiej Rzeczpospolitej Ludowej oraz stanowiskiem prawnym RFN. Podkreślał, że w miejsce rozwiązania traktatowego przyjęto rozwiązanie humanitarne, oparte na porozumieniu międzyrządowym, ponieważ sprawa odszkodowań była pilna ze względu na wiek pokrzywdzonych osób ${ }^{32}$.

Kwestia mniejszości narodowych, odszkodowań i osiedlania się Niemców w Polsce rzeczywiście wzbudziły najwięcej emocji, żaden jednak klub - poza Polskim Stronnictwem Ludowym, nie brał pod uwagę renegocjacji traktatu, ani nie opowiedział się za wstrzymaniem procesu ratyfikacji ${ }^{33}$.

przez stronę polską fundacji, która następnie miała wypłacić odszkodowania, Sprawozdanie stenograficzne z 62 posiedzenia Sejmu w dniach 7 do 8 czerwca 1991 r. (dalej Posiedzenie Sejmu), s. 215, 217, 224, tekst traktatu został zamieszczony w: Polska - Niemcy. Dobre sqsiedztwo i przyjazna wspólpraca, pod red. J. Barcza i M. Tomali, Warszawa 1992, s. 24-34.

${ }^{28}$ Posiedzenie KSZ Sejmu i Senatu 12 IX 1991 r., s. 26.

${ }^{29}$ Posiedzenie Sejmu 7-8 VI 1991 r., s. 213-214, 217; Posiedzenie KSZ Sejmu i Senatu 12 IX 1991 r., s. 27. Pełny tekst przemówienia w: Polska - Niemcy..., s. 34-37.

${ }^{30}$ Posiedzenie Sejmu 12, 13 i 14 września 1991 r., s. 127-130.

${ }^{31}$ Chodziło o Akt Końcowy KBWE z 1 VIII 1975 r., dokument w sprawie ludzkiego wymiaru KBWE z 29 VI 1990 r. i Paryską Kartę Nowej Europy z 21 XI 1990 r.

${ }^{32}$ Posiedzenie Sejmu 12-14 IX 1991 r., s. 130-131.

${ }^{33}$ Posiedzenie Sejmu 12-14 IX 1991 r., s. 143, debata na ten temat na s. 134-159, oprócz tego [w:] Polska - Niemcy..., s. 121-147. 
Posłowie, odnosząc się do traktatu o potwierdzeniu granicy, podkreślali, że ostatecznie pozbawił Związek Radziecki roli jej gwaranta. Odpowiedzialność za bezpieczeństwo swoich granic wzięły na siebie Niemcy i Polska. Wielu posłów akceptowało przyznanie (w traktacie o dobrym sąsiedztwie), że w Polsce mieszka niemiecka mniejszość. Jednak tylko nieliczni (Jan Janowski ze Stronnictwa Demokratycznego) dostrzegli, że w tej sprawie normy polityczne KBWE zostały przekształcone w normy prawne, z czego szczególnie był dumny Krzysztof Skubiszewski, uważając to rozwiązanie za zupełnie nowatorskie ${ }^{34}$.

Debata i głosowanie w Sejmie nad ratyfikacją traktatu o dobrym sąsiedztwie odbyły się 18 października 1991 r., już po ratyfikacji obu traktatów przez Bundestag (17 października 1991 r.) i przyjęciu jego specjalnej uchwały w tej sprawie. Niektóre zapisy uchwały Bundestagu zostały w Polsce przyjęte z oburzeniem ${ }^{35}$.

Debatę otworzył premier Jan Krzysztof Bielecki, podkreślając wyjątkowy charakter obu traktatów: „Od dawna, w długich dziejach polsko-niemieckiego sąsiedztwa, Polacy i Niemcy nie byli tak blisko siebie, nie patrzyli z taką ufnością w przyszłość. Wynika to z głębokiej świadomości, że bez dobrego sąsiedztwa polsko-niemieckiego, bez dobrze rozumianej wspólnoty Polaków i Niemców trudno myśleć o zjednoczonej Europie"36.

Premier podkreślał, że polska droga do integracji ze Wspólnotami Europejskimi wiodła przez Niemcy, które zobowiązały się poprzeć dążenia Polski w tym zakresie. W ten sposób po raz pierwszy Polakom i Niemcom udało się zająć wspólne stanowisko w wielu fundamentalnych sprawach, a to, co ich łączy, ujęto w formę prawną ${ }^{37}$.

W trakcie debaty sprawozdawcy Komisji Spraw Zagranicznych i klubów poselskich wyrazili poparcie dla ratyfikacji traktatu o dobrym sąsiedztwie. Komisja Spraw Zagranicznych, odnosząc się do uchwały Bundestagu, doceniła zawarte w niej stwierdzenie, że oba traktaty są zgodne z wolą wszystkich Niemców, życzących sobie trwałego porozumienia i pojednania z narodem polskim. Stwierdziła jednak, że Polacy i Niemcy nadal różnią się w ocenie swej przeszłości, ale wola pojednania i współpracy powinna zdominować wzajemne stosunki. Posłowie popierający ratyfikację podkreślali zawarty w nim szeroki zakres współpracy i przekonywali, że w celu jej rzeczywistej realizacji należało porzucić postawę strachu wobec Niemiec, ukształtowaną przez lata komunistycznej propagandy. Wzywali do zmiany stosunku do obcokrajowców i podjęcia wysiłku zrozumienia innych ${ }^{38}$.

Krytyka traktatu pojawiła się w indywidualnych wystąpieniach posłów. W jej centrum znalazły się sprawy odszkodowań, statusu niemieckiej mniejszości w Polsce i Polaków w Niemczech, zgoda na zakup przez Niemców nieruchomości w Polsce. Marek Jurek, odnosząc się do tych spraw, oskarżył rząd o dopuszczenie w traktacie sformułowań godzą-

${ }^{34}$ Posiedzenie Sejmu 12-14 IX 1991 r., s. 144, 155-158, 160.

${ }^{35}$ Bundestag w sprawie potwierdzenia granicy użył następującego sformułowania: „Kształtowanie na nowo stosunków między naszymi narodami w środku Europy wypływa więc z niedającego się uniknąć - lecz dla wielu Niemców, zwłaszcza wypędzonych z ojczyzny - bolesnego faktu, że istniejąca niemiecko-polska granica jest ostateczna"; w sprawie rozszerzenia WE deklarował, że perspektywa przyjęcia Polski do WE powinna pozwolić niemieckim obywatelom na osiedlanie się w Polsce; w sprawie odszkodowań Bundestag wyraził zadowolenie, ,że poprzez utworzenie Fundacji »Pojednanie Niemiecko-Polskie« udzielona będzie pomoc ofiarom prześladowań nazistowskich jako końcowy gest humanitarny", pełny tekst uchwały w: Polska - Niemcy..., s. $88-89$.

${ }^{36}$ Sprawozdanie stenograficzne z posiedzenia Sejmu 18 X 1991 r., s. 194.

${ }^{37}$ Sprawozdanie stenograficzne z posiedzenia Sejmu 18 X 1991, s. 193, 195-196.

${ }^{38}$ Sprawozdanie stenograficzne z posiedzenia Sejmu 18 X 1991., s. 196-197, 227-230, 237, 240. 
cych w polską dumę narodową i przyjęcie rozwiązań oznaczających „stwierdzenie szczególnej obecności niemczyzny w Polsce" 39 .

Ze względu na zbliżające się wybory parlamentarne (zaplanowane na 27 października 1991 r.), dyskusję merytoryczną zdeformowała widoczna już walka o głosy, w której kwestia niemiecka była łatwym sposobem do zdobycia poparcia. Prawdziwy atak na niektóre zapisy traktatu o dobrym sąsiedztwie przypuścili posłowie PSL. Ich wystąpienia budowały obraz Polski wykupywanej i zdominowanej gospodarczo przez Niemców, a traktat oceniali, jako wiernopoddańczy akt w stosunku do Niemiec. Narracja ta w pewnym momencie obrad zdominowała dyskusję. Wykorzystał to poseł Jan Łopuszański, przedstawiając własny projekt uchwały w sprawie obu traktatów, konkurencyjny dla projektu opracowanego przez Komisję Spraw Zagranicznych. Domagał się, by poddać go pod głosowanie, zanim posłowie zdecydują o przyjęciu ustawy o ratyfikacji traktatu o dobrym sąsiedztwie. Liczył, że wpłynie w ten sposób na decyzję wielu posłów w sprawie wyrażenia zgody na ratyfikację $e^{40}$.

Niekorzystny obrót dyskusji zmobilizował obrońców traktatu, by przywołać jego zasadnicze wartości. Wiktor Dys-Kulerski (OKP) przekonywał, że ratyfikacja traktatu pozwoli Polakom i Niemcom na wzajemne wyzwolenie się z lęków i bagażu przeszłości, co stało się już udziałem Francuzów i Niemców. Henryk Wujec (OKP) odwołał się do przekazu moralnego, listu biskupów polskich do niemieckich z 1965 r., w którym odrzucono obowiązujące w państwowej propagandzie szowinizm i nienawiść do Niemców w podobnej atmosferze krytyki. Traktat o dobrym sąsiedztwie stanowił, jego zdaniem, powrót na drogę wskazaną przez biskupów. Nie rekompensował wprawdzie krzywd, które domagały się zadośćuczynienia, ale zamykał drogę do przeszłości, szowinizmu i nienawiści ${ }^{41}$.

Bronisław Geremek ostrzegł, że budowanie strachu przed Niemcami ograniczy swobodę Polski w określeniu podstaw jej bezpieczeństwa, które powinny się opierać na „mądrych stosunkach wspólnych interesów"42. Stwierdził, że opieranie polityki na niemieckim zagrożeniu było wprawdzie silnie zakorzenione w polskiej historii, ale reprezentowało koncepcję Polski zamkniętej, przejętej obawą przed wejściem do Europy. Odejście od tej tradycji wymagało odwagi i poszukiwania nowego miejsca Polski w Europie. Wezwał, by nie zniechęcać się oburzającą w wielu miejscach uchwałą Bundestagu, ale dostrzec nowe niemieckie pokolenie, zdecydowane przekreślić tradycję niemieckiej polityki. Wezwał do poparcia obu traktatów mimo ich ułomności, by dać wyraz dobrej woli polskiego narodu w kwestii realizacji ich postanowień ${ }^{43}$.

Ostatecznie posłowie głosowali najpierw nad ratyfikacją traktatu o dobrym sąsiedztwie (182 głosy za, przeciw 26 głosów, wstrzymało się 60); następnie za przyjęciem uchwały w sprawie ratyfikacji przez prezydenta traktatu potwierdzającego granicę (za było 262 posłów, przeciw 1, wstrzymało się 6). Na koniec przyjęto uchwałę w sprawie ratyfikacji obu traktatów przygotowaną przez Komisję Spraw Zagranicznych Sejmu (za 154 głosy, przeciw 54, wstrzymujących się 52), co oznaczało, że projekt posła Łopuszańskiego przepad144.

\footnotetext{
${ }^{39}$ Sprawozdanie stenograficzne z posiedzenia Sejmu 18 X 1991., s. 231.

${ }^{40}$ Posiedzenie Sejmu 18 X 1991 r., s. 241, 243, 245-248, 251-252.

${ }^{41}$ Posiedzenie Sejmu 18 X 1991 r., s. 252-254.

${ }^{42}$ Posiedzenie Sejmu 18 X 1991 r., s. 256.

${ }^{43}$ Posiedzenie Sejmu 18 X 1991 r., s. 256-257.

${ }^{44}$ Posiedzenie Sejmu 18 X 1991 r., s. 265-266, 272.
} 
Uchwała Sejmu w sprawie ratyfikacji obu traktatów była sformułowana w chłodny sposób, na co niewątpliwie miała wpływ uchwała Bundestagu. Sejm uznał doniosłość obu podpisanych traktatów jako podstawy pokojowego współżycia obu narodów. Podkreślił wagę uregulowania kwestii granicy i wzajemnego wyrzeczenia się roszczeń terytorialnych. Wyraził zadowolenie z poparcia, jakiego Niemcy obiecały udzielić Polsce w drodze do Wspólnot Europejskich. Uznał prawo mniejszości narodowych za fundamentalne prawo człowieka - zgodnie z przyjętymi standardami międzynarodowymi, i oczekiwał respektowania praw polskiej mniejszości w Niemczech. Wyraził ubolewanie z braku pełnego uregulowania problemu odszkodowań dla ofiar zbrodni nazistowskich, zaś fakt zawarcia porozumienia w tej sprawie (16 października 1991 r.) jedynie przyjął do wiadomości ${ }^{45}$.

Debata ratyfikacyjna w Senacie odbyła się 23 października 1991 r. Traktat o dobrym sąsiedztwie przedstawił Krzysztof Skubiszewski, a przewodniczący Komisji Spraw Zagranicznych Senatu, Stanisław Dembiński wezwał, by senatorowie bez dyskusji wyrazili zgodę na jego ratyfikację, przyjęli uchwałę w sprawie ratyfikacji przez prezydenta traktatu o potwierdzeniu granicy oraz własną uchwałę w sprawie obu traktatów ${ }^{46}$.

Krzysztof Skubiszewski, prezentując traktat o dobrym sąsiedztwie, porównał jego znaczenie do pojednania francusko-niemieckiego. Powtórzył, że traktat otwierając granicę dla osób, towarów i usług, tym samym otwierał Polskę na Europę i na Niemcy: „współżycie polsko-niemieckie może i powinno być nośnikiem zrastania się obu części Europy w jedną całość”. Jego zdaniem traktat stał się „,...podstawą prawną i polityczną dla wspólnoty losów i interesów Polaków i Niemców w jednoczącej się Europie..." ${ }^{47}$. Podkreślił fundamentalne znaczenie traktatu dla integracji Polski z Zachodem i nie wattpił, że od współpracy z Niemcami będzie zależało powodzenie i losy polskiej opcji europejskiejej.

Senatorowie wskazywali jednak najważniejsze, ich zdaniem, wady obu traktatów: brak odniesienia do sporu o Zatokę Pomorską; pominięcie sprawy odszkodowań; brak zdefiniowania Polaków w Niemczech jako mniejszości; wyrzeczenie się wspólnie z Niemcami antysemityzmu, co uznano za niestosowne ${ }^{49}$.

Większość senatorów podkreślała jednak zmianę, jaka miała nastąpić w międzynarodowym położeniu Polski po zawarciu obu traktatów. Granica zachodnia Polski nie miała już opierać się na decyzji mocarstw, ale na woli Polaków i Niemców (Dorota Symonides). Dzięki temu obalono „dogmat” o roli Związku Radzieckiego jako jej jedynego gwaranta, co pozwalało Polsce ostatecznie opuścić radziecką strefę wpływów (Janusz Ziółkowski) ${ }^{50}$.

${ }^{45}$ Uchwała Sejmu Rzeczypospolitej Polskiej z dnia 18 października $1991 \mathrm{r}$. w sprawie traktatów zawartych między Rzeczapospolita Polskq a Republikq Federalnq Niemiec, traktatu o dobrym sqsiedztwie i przyjaznej wspótpracy, podpisanego w Bonn 17 czerwca 1991 r., oraz o potwierdzeniu istniejacej między nimi granicy, podpisanego w Warszawie 14 listopada 1990 r., infor.pl/monitor-polskir.1991/4/rok 1991, nr 36, poz. 262 (dostęp: 8 IX 2019). Porozumienie z 16 X 1991 r. miało formę wymiany listów między Sekretarzem Stanu MSZ Republiki Federalnej Niemiec Dieterem Kastrupem a Szefem Urzędu Rady Ministrów Rzeczypospolitej Polskiej Krzysztofem Żabińskim. Tekst obu listów w: Polska - Niemcy..., s. 242.

${ }^{46}$ AS, Sprawozdanie stenograficzne z posiedzenia Senatu w dniu 23 X 1991 r. (dalej Posiedzenie Senatu), s. $23-24$.

${ }^{47}$ Posiedzenie Senatu, s. 30.

${ }^{48}$ Posiedzenie Senatu, s. 29-30.

${ }^{49}$ Posiedzenie Senatu, wypowiedzi Mieczysława Ustasiaka, Romana Ciesielskiego, Augusta Chełkowskiego, s. 31, 36-37, 56.

${ }^{50}$ Posiedzenie Senatu, s. 33, 49. 
Ratyfikację obu traktatów gorąco poparł Stanisław Stomma, osobiście zaangażowany w polsko-niemieckie pojednanie. Andrzej Szczypiorski traktował zaś ich podpisanie jako zwycięstwo rozumu i zdrowego rozsądku, odrzucenie obaw, które służyły jednoczeniu polskiego narodu na tak zwanej platformie antyniemieckiej. Uważał, że dążenie do zjednoczonej Europy było jedyną drogą dla Polski, a prowadziła ona wyłącznie przez Niemcy. Ratyfikację traktatów uznał za początek drogi obu narodów ku przyszłości. Należało nią podążać, zachowując pamięć tego, co się kiedyś w historii zdarzyło, ale w kierunku pełnego pojednania, pełnego wybaczenia, a co za tym idzie - owocnej współpracy ${ }^{51}$.

Senatorów niepokoił chłodny ton uchwały Sejmu odnoszącej się do obu traktatów oraz brak zrozumienia dla ich doniosłości ze strony społeczeństwa. Ryszard Reiff i Walerian Piotrowski obawiali się zwycięstwa stereotypu niemieckiego zagrożenia, co mogło zagrozić realizacji postanowień traktatu o dobrym sąsiedztwie ${ }^{52}$.

Senatorowie jednomyślnie przyjęli ustawę o ratyfikacji traktatu o dobrym sąsiedztwie (obecnych 72, głosowało 71, wszyscy za). Za uchwałą popierającą ratyfikację traktatu o potwierdzeniu granicy przez prezydenta głosowało 69 senatorów, dwóch wstrzymało się od głosu $^{53}$. Senat przyjął także uchwałę w sprawie Traktatu między Rzeczapospolita Polska a Republika Federalnq Niemiec o dobrym sqsiedztwie i przyjaznej wspótpracy podpisanego w Bonn dnia 17 czerwca 1991 r. oraz traktatu między Rzeczapospolita Polska a Republika Federalnq Niemiec o potwierdzeniu istniejacej między nimi granicy, podpisanego w Warszawie dnia 14 listopada 1990 r. większością 67 głosów przy czterech wstrzymujących się ${ }^{54}$.

W swej uchwale Senat stwierdzał, że oba traktaty stanowią polityczną całość. Zamykają miniony okres i tworzą perspektywę współpracy obu państw w nowej Europie. Ich podpisanie było możliwe, ponieważ zaistniała „zbieżność obustronnych interesów”. Senat podkreślał rolę przemian zapoczątkowanych w Polsce w 1980 r. dla odzyskania przez Niemcy politycznej jedności. Docenił uznanie przez państwo niemieckie granicy z Polską za ostateczną i nienaruszalną oraz zobowiązanie do wspierania dążenia Polski do Wspólnot Europejskich. Wskazywał, że oba państwa powinny wykazać zrozumienie dla istniejących uprzedzeń, a pojednanie musi zostać poparte zarówno przez pokolenie, które przeżyło wojnę, jak i urodzone po wojnie. Senat przyjął powołanie Fundacji Pojednanie Polsko-Niemieckie z zadowoleniem, a postanowienia dotyczące mniejszości narodowych uznał za ,cenny dorobek zgodny z obowiązującymi standardami międzynarodowymi i tworzący zarazem nowe wzorce w stosunkach międzynarodowych"

\section{Zakończenie}

W latach 1989-1991 r. polsko-niemieckie stosunki nie tylko wyszły z głębokiego impasu, w jakim pozostawały od 1981 r., ale zostały zupełnie przewartościowane. W poszukiwaniu płaszczyzny efektywnej współpracy z Niemcami został określony zakres pol-

\footnotetext{
${ }^{51}$ Posiedzenie Senatu, s. 42, 44-48.

${ }^{52}$ Posiedzenie Senatu, s. 37-40, 51-53.

${ }^{53}$ Posiedzenie Senatu, s. 62-63.

${ }^{54}$ Posiedzenie Senatu, s. 68.

${ }^{55}$ Posiedzenie Senatu, s. 305-306.
} 
sko-niemieckiej „wspólnoty interesów” jako dążenia do umocnienia i rozszerzenia integracji europejskiej. Koncepcja ta została zaakceptowana przez sejmową większość, chociaż z pewną rezerwą. Wielu posłów oburzało zamknięcie przeszłości bez wyegzekwowania odszkodowań drogą traktatową. $Z$ trudem przychodziło pogodzenie się z istnieniem w Polsce niemieckiej mniejszości, domagającej się zagwarantowania swych praw, podczas gdy Polacy w Niemczech nie uzyskali statusu mniejszości.

Zasługą Sejmu i Senatu, wybranych 4 czerwca 1989 r., było zrozumienie, że współpraca z Niemcami zmieniła w zupełności geopolityczne położenie Polski. Nie było już determinowane przez wrogie nastawienie Republiki Federalnej Niemiec, dla którego Polska musiała szukać przeciwwagi we współpracy ze Związkiem Radzieckim. Nie udało się natomiast wyeliminować wykorzystywania antyniemieckich sentymentów jako trampoliny do uzyskania społecznego poparcia w walce politycznej. Manipulowanie nimi nie sprzyjało, i nie sprzyja, utrwalaniu w polskiej świadomości faktu, że Polska i Niemcy mogą mieć i mają wspólne długotrwałe cele.

\section{Bibliografia}

Archiwum Senatu

Andrzej Stelmachowski, Zespół 48 teczka Europa.

Sprawozdanie stenograficzne z posiedzenia Senatu w dniu 23 X 1991 r.

Dokumenty sejmowe

Sprawozdanie stenograficzne z 62 posiedzenia Sejmu w dniach 7 do 8 czerwca 1991 r., orka2.sejm. gov.pl.

Sprawozdanie stenograficzne z 73 posiedzenia Sejmu Rzeczypospolitej Polskiej w dniach 12, 13 i 14 września 1991 r., orka2.sejm.gov.pl.

Sprawozdanie stenograficzne z 78 posiedzenia Sejmu Rzeczypospolitej Polskiej w dniach 16, 17, 18, 19 października 1991 r., orka2.sejm.gov.pl.

Sprawozdanie stenograficzne z posiedzenia Komisji Spraw Zagranicznych Sejmu w dniu 8 IX 1989 r. Warszawa 1989.

Sprawozdanie stenograficzne z posiedzenia Komisji Spraw Zagranicznych Sejmu i Senatu w dniu 17 X 1989 r., Warszawa 1989.

Sprawozdanie stenograficzne z posiedzenia Komisji Spraw Zagranicznych Sejmu i Senatu w dniu 16 II $1990 r$. Warszawa 1989.

Sprawozdanie stenograficzne z posiedzenia Komisji Spraw Zagranicznych Sejmu, w dniu 25 VII 1990 r., Warszawa 1990.

Sprawozdanie stenograficzne z posiedzenia Komisji Spraw Zagranicznych Sejmu i Senatu w dniu 12 IX $1991 r$., Warszawa 1991.

Dokumenty publikowane

Polska-Niemcy. Dobre sqsiedztwo i przyjazna wspótpraca, pod redakcją Jana Barcza i Mieczysława Tomali, Warszawa 1992.

Polska wobec zjednoczenia Niemiec 1989-1991, pod redakcją Włodzimierza Borodzieja, Warszawa 2006.

Uchwała Sejmu Rzeczypospolitej Polskiej z dnia 18 października 1991 r.w sprawie traktatów zawartych między Rzeczapospolita Polskq a Republikq Federalna Niemiec o dobrym sqsiedztwie 
i przyjaznej wspótpracy, podpisanego w Bonn 17 czerwca 1991 r., oraz o potwierdzeniu istniejacej między nimi granicy, podpisanego w Warszawie 14 listopada 1990 r., infor.pl/monitorpolskir.1991/4/rok 1991, nr 36, poz. 262.

Opracowania

Parzymies S., Stosunki międzynarodowe w Europie 1945-2004, Warszawa 2004.

Prace zbiorowe

Polska-Niemcy 1945-2007. Od konfrontacji do wspótpracy i partnerstwa w Europie. Studia i dokumenty, pod redakcją Witolda M. Góralskiego, Warszawa 2007.

Artykuły

Czapliński W., Polskie pozycje prawne wobec Niemiec popoczdamskich w świetle prawa międzynarodowego. Agresja-terytorium-obywatelstwo, [w:] Polska-Niemcy 1945-2007. Od konfrontacji do wspótpracy i partnerstwa w Europie. Studia i dokumenty, pod redakcją Witolda M. Góralskiego, Warszawa 2007.

Góralski W. M., Polsko-niemiecka wspólnota interesów. Geneza, dokonania, zagrożenia, [w:] Polska-Niemcy 1945-2007. Od konfrontacji do wspótpracy i partnerstwa w Europie. Studia i dokumenty, pod redakcją Witolda M. Góralskiego, Warszawa 2007.

Agnieszka Malgorzata Kastory, dr hab., aktualnie jest zatrudniona na stanowisku profesora nadzwyczajnego Uniwersytetu Jagiellońskiego w Katedrze Stosunków Międzynarodowych i Polityki Zagranicznej Instytutu Nauk Politycznych i Stosunków Międzynarodowych. Do jej najważniejszych publikacji należą: Rozbiór Rumunii w 1940 roku, Warszawa 2002; Żegluga dunajska w polityce międzynarodowej w XX wieku, Kraków 2011; Rola Obywatelskiego Klubu Parlamentarnego w ksztattowaniu polskiej polityki wschodniej w latach 1989-1991, Kraków 2018. 